Folia Cardiologica 2016 tom 11 , nr 4, strony 348-352 DOI: $10.5603 / F C .2016 .00 x x$ Copyright (c) 2016 Via Medica ISSN 2353-7752

\title{
Ebstein's anomaly treated surgically in an adult female
}

\section{Anomalia Ebsteina leczona operacyjnie u dorosłej pacjentki}

\author{
Andrzej Gackowski ${ }^{1,2}$, Magdalena Maria Frączek-Jucha ${ }^{1}$, Radosław Rychlak ${ }^{1}$, Patrick Perier ${ }^{3}$, \\ Jacek Pająk ${ }^{4}$, Szymon Pawlak ${ }^{5}$, Jadwiga Nessler ${ }^{1}$ \\ ${ }^{1}$ Department of Coronary Disease and Heart Failure, Jagiellonian University Medical College, John Paul II Hospital, Krakow, Poland \\ ${ }^{2}$ Noninvasive Cardiovascular Laboratory, John Paul II Hospital, Krakow, Poland \\ ${ }^{3}$ Cardiovascular Centre, Bad Neustadt/Saale, Germany \\ ${ }^{4}$ Department of Pediatric Cardiology, School of Medicine in Katowice, Poland \\ ${ }^{5}$ Department of Cardiac Surgery and Transplantology in Zabrze, Silesian Medical University, Poland
}

\section{Abstract}

A 21-year-old woman with Ebstein's anomaly was admitted with syncope on exertion, fatigue and dyspnea (NYHA III). Physical examination revealed systolic apical murmur. Echocardiography showed normal LVEF, apical displacement of the septal tricuspid leaflet, severe tricuspid regurgitation, right ventricle dilatation and dysfunction. After detailed evaluation, surgery of the right atrioventricular ostium was proposed. Five months after surgery the patient reported an improvement in exercise tolerance (NYHA II). Echocardiography showed mild residual tricuspid regurgitation.

Key words: Ebstein's anomaly, congenital heart diseases

Folia Cardiologica 2016; 11, 4: 348-350

\section{Introduction}

A 21-year-old woman with Ebstein's anomaly (EA) was admitted with syncope on exertion, fatigue and dyspnea (NYHA III). She was previously evaluated in several centers and considered inoperable.

\section{Examination}

Physical examination revealed systolic apical murmur. Resting ECG and Holter monitoring did not disclose abnormalities. Echocardiography showed normal LVEF. There was a $24 \mathrm{~mm}$ apical displacement of the septal tricuspid leaflet (STL) and right ventricle (RV) dilatation and dysfunction. The area of the atrialized portion of RV was $13 \mathrm{~cm}^{2}$ and the functional RV area $29 \mathrm{~cm}^{2}$. The tricuspid valve annulus was severely dilated $(53 \mathrm{~mm}$ ) and a central $9 \mathrm{~mm}$ coaptation defect was a cause of severe tricuspid regurgitation (TR) - PISA $15 \mathrm{~mm}$, VC $13 \mathrm{~mm}$, ERO $1.04 \mathrm{~cm}^{2}$. RVSP was $38 \mathrm{~mm} \mathrm{Hg}$ (Fig. 1). A six-minute walk test revealed significant limitation of exercise capacity compared to a test done 4 years previously ( 210 vs. 450 metres). Cardiopulmonary exercise tests showed decreased $\mathrm{VO}_{2}$ max $-13.9 \mathrm{ml} / \mathrm{kg} /$ /min. Cardiac catheterization revealed a cardiac index of $2.56 \mathrm{~L} / \mathrm{min} / \mathrm{m}^{2}$.

\section{Surgery}

After detailed evaluation, surgery of the right atrio-ventricular ostium was proposed. The procedure involved 


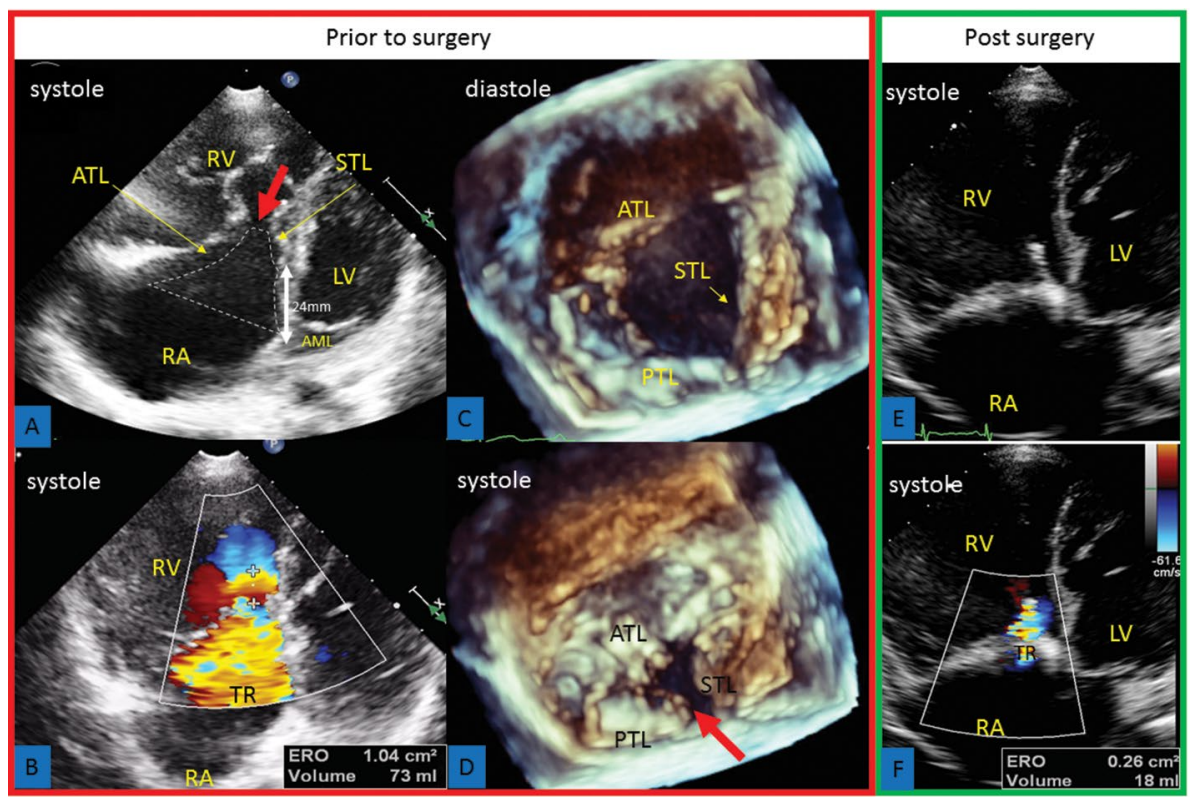

Figure 1A-F. Modified 4-chamber view (panels A and B). Typical for Ebstein's anomaly displacement of the septal tricuspid leaflet (STL), it is located at a distance of $24 \mathrm{~mm}$ from the anterior mitral leaflet (AML) - white arrow. The atrialized portion of the right ventricle is shown by the dashed line. The coaptation gap (red arrow) cause severe tricuspid regurgitation (TR) shown on panel B. Three-dimensional echocardiography (panels $\mathbf{C}$ and $\mathbf{D}$ ) presenting diastolic and systolic views of the tricuspid valve confirm a large coaptation defect (red arrow) caused by pathology of the STL and annulus dilatation. Panels $E$ and $F$ show improved coaptation and a significant reduction in regurgitation after surgical plasty of the tricuspid valve. It was confirmed by significant reduction in the effective regurgitant orifice (ERO) and regurgitant volume; ATL - anterior tricuspid leaflet; RV - right ventricle; LV - left ventricle; RA - right atrium; PTL - posterior tricuspid leaflet

plication of the atrialized RV, liberation and plasty of tricuspid leaflets, and implantation of an artificial leaflet made of autologous pericardium, Gore-Tex chords, and an undersized Edwards Lifesciences Classic $34 \mathrm{~mm}$ ring. The perioperative period was complicated by RV failure treated with catecholamines.

\section{Follow-up}

Five months after surgery the patient reported an improvement in exercise tolerance (NYHA II). Echocardiography showed mild residual TR-PISA $4 \mathrm{~mm}, \mathrm{VC} 3 \mathrm{~mm}, \mathrm{ERO} 0.26 \mathrm{~cm}^{2}$, RVSP $24 \mathrm{~mm} \mathrm{Hg}$ (Fig. 1). RV dysfunction was present. A cardiopulmonary exercise test showed moderate improvement of $\mathrm{VO}_{2} \mathrm{max}-15.7 \mathrm{ml} / \mathrm{kg} / \mathrm{min}$.

\section{Discussion}

The morphology and clinical course of EA varies and depends on the severity of the TR, the degree of RV atrialization and both RV and LV function. Tricuspid valve repair was previously not very successful but outcomes are now promising thanks to new operating techniques and better preoperative evaluation, including 3D echocardiography. Indications for surgical repair include severe TR and NYHA class higher than II or arrhythmias or deteriorating exercise capacity
[1-3]. In selected EA cases, TV plasty and reduction of RV size is believed to be the best method of correction. The formation of a "cone" or double-leaflet valve is recommended to ensure normal function of the newly created TV [4-6]. The septal and/or posterior cusp of the tricuspid valve is absent in high-grade EA (in our patient), which makes the reconstruction of a double-leaflet valve impossible. In such cases, an artificial valve needs to be implanted. Patients with such valves require prolonged antithrombotic treatment and a repeat operation is frequently needed. In such patients the best alternative would be the Perier method of TV plasty, in which a TV cusp is created from the patient's pericardium and its free margin fixed with artificial chords.

\section{Conclusions}

This case proves improvement after surgery. The course was complicated due to RV dysfunction. It is possible that this could have been avoided if the patient was operated on at an earlier stage of disease. The case illustrates the difficulties in decision making and the correct timing of surgery in this patient group.

\section{Conflict of interest}

None declared. 


\section{Streszczenie}

Pacjentka w wieku 21 lat $z$ anomalią Ebsteina została przyjęta do szpitala z powodu zasłabnięć w trakcie wysiłku fizycznego, zmęczenia i duszności (III klasa wg NYHA). W badaniu przedmiotowym był obecny szmer skurczowy nad koniuszkiem serca. W badaniu echokardiograficznym stwierdzono: prawidłową frakcję wyrzutową lewej komory, przemieszczenie przegrodowego płatka zastawki trójdzielnej w głąb prawej komory, ciężką niedomykalność zastawki trójdzielnej, powiększenie i dysfunkcję prawej komory. Po wnikliwej ocenie klinicznej pacjentkę zakwalifikowano do plastyki zastawki trójdzielnej. Pięć miesięcy po operacji chora zgłaszała znaczną poprawę tolerancji wysiłku fizycznego (II klasa wg NYHA). W badaniu echokardiograficznym zobrazowano łagodną niedomykalność zastawki trójdzielnej.

Słowa kluczowe: anomalia Ebsteina, wady wrodzone serca

Folia Cardiologica 2016; 11, 4: 348-350

\section{References}

1. Baumgartner H., Bonhoeffer P., De Groot N.M. at al. ESC Guidelines for the management of grown-up congenital heart disease (new version 2010). Eur. Heart J. 2010; 31: 2915-2957.

2. Arya P., Beroukhim R. Ebstein anomaly: assessment, management, and timing of intervention. Curr. Treat. Options Cardiovasc. Med. 2014; 16: 338.

3. Booker O.J., Nanda N.C. Echocardiographic assessment of Ebstein's anomaly. Echocardiography 2015; 32 (Suppl 2): 69-80.

4. Da Silva J.P., Baumgratz J.F., Da Fonseca L. et al. The cone reconstruction of the tricuspid valve in Ebstein's anomaly. The operation: early and midterm results. J. Thorac. Cardiovasc. Surg. 2007; 133: 215-223.

5. Ibrahim M., Tsang V.T., Caruana M. et al. Cone reconstruction for Ebstein's anomaly: Patient outcomes, biventricular function, and cardiopulmonary exercise capacity. J. Thorac. Cardiovasc. Surg. 2015; 149: 1144-1150.

6. Dearani J.A., Mora B.N., Nelson T.J. et al. Ebstein anomaly review: what's now, what's next? Expert Rev. Cardiovasc. Ther. 2015; 13: 1101-1109. 